\title{
The Effect of Peri-Implant Disease on Oxidative Stress Markers Levels in Peri- Implant Sulcus Fluid: A Cross-Sectional, Pilot Study
}

\section{Peri-İmplant Hastalığın Peri-IImplanter Sulkus Sıvısında Oksidatif Stres Belir- teçleri Seviyeleri Üzerindeki Etkisi: Kesitsel, Pilot Çalışma}

\author{
Emre BiRBiRi ${ }^{1}(\mathbb{D})$, Meral UZUNKAYA ${ }^{2} \mathbb{D}$, Hasan GÜNDOĞAR ${ }^{3,4} \mathbb{D}$
}

\author{
1 Private Practise, Adana, Turkey. \\ 2 Kahramanmaraş Sütçü İmam University, Faculty of Dentistry, Peridontology Department, Kahramanmaraş, Turkey. \\ ${ }^{3}$ Gaziantep University, Faculty of Dentistry, Peridontology Department, Gaziantep, Turkey \\ ${ }^{4}$ Khoja Akhmet Yassawi International Kazakh-Turkish University, Faculty of Dentistry, Surgery and Pediatric Dentistry \\ Department, Turkestan, Kazakhstan.
}

\begin{abstract}
Background: Peri-implant diseases are inflammatory diseases as periodontal disease. An array of oxidative stress markers has been examined in the disease and health of the periodontal tissues. The purpose of the study was to test whether peri-implant conditions have an impact on the peri-implant sulcus fluid oxidative stress markers.

Materials and Methods: A total of 44 participants were included in the study. Collected samples divided 3 groups, 14 samples for healthy implants; 15 samples for peri-implant mucositis; and 15 samples for peri-implantitis. In clinical periodontal examination, plaque index (PI), modified bleeding index (mSBI), probing bleeding (BOP), probing pocket depth (PPD), gingival index (GI), modified plaque index (MPI) were measured. Periimplant sulcus fluid (PISF) samples were collected for evaluating and measuring biochemical analysis of total oxidant status (TOS) and total antioxidant capacity (TAOC) and oxidative stress index (OSI).

Results: The TOS level in PISF was statistically significantly higher in the peri-implantitis when compared to the healthy group $(p=0.041)$. There was no statistically significant difference $(p>0.05)$ between groups in terms of TAOC and OSI parameters.

Conclusions: As a result of the current study, it can be said that, due to its inflammatory character, peri-implantitis can increase total oxidant status (TOS) in peri-implant sulcus fluid (PISF). Multicentered research is needed to explain which immunological mechanism triggers the oxidative system in peri-implantitis in order to understand the potential role of oxidative stress markers in peri-implant inflammation.
\end{abstract}

Key Words: Oxidative Stress, Peri-Implant Disease, Peri-Implant Sulcus Fluid, Peri-Implantitis, Peri-Implant Mucositis

öz.

Amaç: Peri-implant hastalıklar, periodontal hastalık gibi inflamatuar hastalıklardır. Periodontal hastalık ve sağlık durumunda bir dizi oksidatif stres belirteci incelenmiştir. Bu çalışmanın amacı, peri-implant durumların, peri-implant sulkus sıvısı oksidatif stres belirteçleri üzerindeki etkisini olup olmadığııı test etmektir.

Materyal ve Metod: Çalışmaya toplam 44 katııımcı dahil edildi. Toplanan numuneler sağlıkı implantlar grubu için 14 örnek; peri-implant mukozitis için 15 örnek; ve peri-implantitis için 15 örnek olacak şekilde 3 gruba ayrıldı. Klinik periodontal muayenede; plak indeksi (PI), modifiye kanama indeksi (mSBI), sondalamada kanama indeksi (BOP), sondalanabilir cep derinliği (PPD), gingival indeks (GI), modifiye plak indeksi (MPI) ölçüldü. Total oksitatif stres (TOS) ve total antioksidan kapasitenin (TAOC) biyokimyasal olarak analiz etmek ve oksidatif stres indeksi (OSI) ölçmek için peri-implant sulkus sıvısı (PISF) örnekleri toplandı.

Bulgular: PISF'deki TOS düzeyi, sağlıklı grupla karşılaştırıldığında peri-implantitis grubunda istatistiksel olarak anlamlı derecede yüksekti $(p=0,041)$. TAOC ve OSI parametreleri açısından gruplar arasında istatistiksel olarak anlamlı farklılık yoktu ( $p>0.05)$.

Sonuç: Mevcut çalışma sonucunda, peri-implantitisin inflamatuar karakteri nedeniyle PISF içerisindeki TOS seviyesini artırabileceği söylenebilir. Peri-implantitiste oksidatif stres belirteçlerinin peri-implant inflamasyondaki potansiyel rolünü anlamak ve hangi immünolojik mekanizmanın oksidatif sistemi tetiklediğini açıklayabilmek için çok merkezli araştırmalara intiyaç vardır.

Anahtar kelimeler: Oksidatif stres, Peri-implant hastalık, Peri-implant oluk sıvısı

\section{Corresponding Author / Sorumlu Yazar}

\section{Dr. Meral UZUNKAYA}

Kahramanmaraş Sütçü İmam University, Faculty of Dentistry, Peridontology Department, Kahramanmaraş, Turkey

E-mail: uzunkaya_meral@hotmail.com

Received / Geliş tarihi: 08.03.2021

Accepted / Kabul tarihi: 08.11.2021

DOI: $10.35440 /$ hutfd. 892938 


\section{Introduction}

Dental implant applications are often used to restore lost teeth due to decay, periodontal disease, or trauma. In many different clinical situations, it is also preferred because of its predictability (1). On the other hand, dental implants have long-term complications as well. Recently, inflammation in the peri-implant area and the resulting marginal bone loss have been identified as significant symptoms for peri-implant disease that we can accept as complication(2) . At the 2017 workshop, peri-implant diseases were included in the periodontal disease classification and divided into four categories. These include periimplant health $(H)$, peri-implant mucositis $(P M)$, peri-implantitis (PI) and peri-implant soft and hard tissue deficiencies (3).

Peri-implant diseases are characterized by bleeding on probing (BOP), erythema, and suppuration symptoms (4). The main clinical feature of PM is BOP. Erythema or suppuration may also be present. The increased peri-implant pocket depth can often be observed in PM's presence due to inflammation or decreased probing resistance (5). Periimplantitis is a microbial dental plaque-related pathophysiological situation that occurs in the soft and hard tissues around the dental implants, defined by inflammation of the peri-implant hard and soft tissue and loss of alveolar bone around the dental implant. Peri-implantitis show clinical signs such as inflammation, BOP, suppuration, increased probing depth or recession of the mucosal margin, and mainly marginal alveolar bone loss (2).

Because of peri-implant diseases' inflammatory characteristics, they have parameters and indexs that can be monitored clinically and biochemically. Plaque index, gingival index, periodontal pocket depth, and BOP parameters are recorded clinically for peri-implant diseases. These indexes allow the evaluation of the disease practically in the clinic (6). Biochemically, the levels of various biomarkers, such as cytokines and growth factors from the peri-implant sulcus fluid (PISF) of the implants can be examined (7). Also, oxidative stress markers can be analyzed.

Cellular metabolism produces free radicals naturally. A free radical can be defined as an atom or molecule containing one or more unpaired electrons in valency sheller outer orbit and is capable of independent existence. Sometimes, these free radicals leaking from the active sites of enzymes, by chance, interact with molecular oxygen and form free oxygen radicals (8). There are mechanisms known as "antioxidant defense systems" or simply "antioxidants" in the cell to prevent damage caused by reactive oxygen species. Oxidative stress is defined as more reactive oxygen species than eliminated through antioxidant defense systems (9). Oxidative stress happens when the instability between free oxygen radicals and the antioxidant protection system. Studies suggest that oxidative stress may be associated with atherosclerosis and diabetes, as well as with periodontal diseases (10). Oxidative stress is thought to have effects not only systemically but also locally, such as the oral cavity, in the pathogenesis of salivary gland dysfunction, xserostomia, periodontitis, premalignant and malignant conditions. However, oxidative stress may play a role in the development of possible complications of systemic diseases that may affect the oral cavity and also periodontium as a part of oral cavity (11).

Oxidative stress markers were measured in gingival crevicular fluid (GCF) samples collected from periodontitis cases. Similarly, studies are showing that it can also be measured in PISF samples. In other words, it is possible to evaluate the TAOC, TOS, and OSI levels of the PISF of the implants. In line with this information, our hypothesis; peri-implantitis and oxidative stress might be associated so our research is targeting to evaluate oxidative stress impact on peri-implanter diseases.

\section{Materials and Methods}

A total of 44 individuals, 20 males, and 24 females, aged between 22 and 75 years, were included in this cross-sectional research. A signed informed consent form was taken from all individuals. The study was approved by Gaziantep University Local Ethics Committee (approval date: 23.10.2019, decision number: 399)

\section{Inclusion and Exclusion Criteria}

Patients have no systemic disease, have not used antibiotics or oral contraceptives and have not received any periodontal therapy in the last six months were included. Patients who were in pregnancy or lactation period, substance addicts, patients who did not have implants applied in another hospital in their mouth, or patients with implants functional for less than 24 months were not included in the study. For peri-implant mucositis group; samples were taken from areas with peri-implant inflammation without bone loss. For peri-implantitis group; samples were taken from the inflamed site with progressive bone loss after initial bone remodeling. Also patients with routine oral hygiene habits (those who state that they brush at least 2 times a day) were included.

\section{Clinical Examination}

The study was consisted of Peri-implantitis (PI) group $(n=15)$, peri-implant mucositis group (PM) $(n=15)$ and health peri-implant condition group $(H)(n=14)$. All clinical diagnoses were according to the 2017 EFP and AAP workshop (12). All clinical examinations were performed by a pre-calibrated clinician (M.U.) by using a plastic periodontal probe for the implant (Hu-Friedy, USA) and by using Williams periodontal probe for teeth (Hu-Friedy, USA). Gingival Index (tGI)(13), Plaque index (tPI)(14), periodontal pocket depth (tPPD), clinical attachment level (tCAL) were measured from six surfaces of all teeth, and the average value was calculated for each patient. Furthermore, Plaque index (sPI), periodontal pocket depth (sPPD), and modified sulcus bleeding index (sSBI)(15) were measured from four surfaces of dental implant. Marginal bone loss of dental im- 
plants was measured by using Image J software from standardized periapical radiographs (National Institutes of Health [NIH], Bethesda, MD, USA).

\section{Collection of PISF samples}

Peri-implanter sulcus fluid (PISF) samples were taken one day after clinical examination, dental implant, and peri-implanter area were isolated with cotton pads, gently dried with air spray. Paper strips (Periopaper, Orafow Inc., USA) were placed in the peri-implanter pocket until pressure was felt. After 30 seconds, the paper strips were placed in the pre-calibrated Periotron 8000 device to measure the PISF volume. Samples were stored at -80 degrees until biochemical analysis day. Oxidative stress marker analysis was made according to Erel et al.'s study (16) and instruction of biochemical kits. Total oxidative status (TOS) was expressed as $\mu$ molH2O2 Equiv./L, total antioixdant capacity (TAOC) was described as mmol Trolox Equiv./L. The oxidative stress index (OSI) was counted by the ratio of TOS to TAOC.

\section{Statistical Examination}

It was estimated that 12 patients for each group were required to determine the mean TOS difference of 1 unit (standard deviation 0.85 ) between the two groups and obtain $80 \%$ power. Shapiro Wilk test tested the normality of numerical data. Kruskal Wallis tests were used to compare non-normally distributed data in all groups. Relationships between categorical variables were tested with Chi-square test, and the relationships between numerical variables were tested with the Spearman rank correlation coefficient. Clinical and biochemical data were given as mean \pm standard deviation for descriptive statistics. SPSS v22.0 package program was used in the analyzes. $\mathrm{P}<0.05$ was considered statistically significant.

\section{Results}

\section{Demographic Results}

Comparison of demographic data of the individuals included in the study between groups is shown in Table 1 . The average age \pm standard deviation value of the participants is $52.77 \pm 13.73$. Forty-four samples were collected from 20 male and 24 female patients between the ages of 22-75. There were no statistically significant in terms of age and gender $(p<0.05)$.

Table 1. Comparison of demographic data between groups

\begin{tabular}{|l|l|l|l|l|}
\hline \multicolumn{2}{|l|}{} & H (n=14) & PM (n=15) & PI (n=15) \\
\hline Age & $52,29 \pm 15,89$ & $53,07 \pm 15,01$ & $52,93 \pm 10,92$ \\
\hline \multirow{2}{*}{ Sex } & Male & 6 & 7 & 7 \\
\cline { 2 - 5 } & Female & 8 & 8 & 8 \\
\hline $\begin{array}{l}\text { H: peri-implant health group, PM: peri-implant mucositis group, PI: } \\
\text { peri-implantitis group }\end{array}$ \\
\hline
\end{tabular}

\section{Clinical and Biochemical Results}

The intergroup changes and comparisons of clinical and laboratory findings, including PISF volume oxidative stress markers (TAOC, TOS, OSI) levels and tGI, tPI, tPPD, tCAL, sPI, SPPD, SSBI, and MBL are given in Table 2.
Table 2. Clinical and biochemical parameters of all groups

\begin{tabular}{|l|c|c|c|}
\hline & $\mathbf{H}$ & $\mathbf{P M}$ & $\mathbf{P I}$ \\
\hline tPI & $1,11 \pm 0,43^{\mathrm{a}}$ & $1,23 \pm 0,38^{\mathrm{a}}$ & $1,20 \pm 0,32^{\mathrm{a}}$ \\
\hline tGI & $1,17 \pm 0,13^{\mathrm{a}}$ & $1,24 \pm 0,12^{\mathrm{a}}$ & $1,33 \pm 0,27^{\mathrm{a}}$ \\
\hline tPPD & $1,84 \pm 0,72^{\mathrm{a}}$ & $1,93 \pm 0,64^{\mathrm{a}}$ & $2,40 \pm 0,55^{\mathrm{a}}$ \\
\hline sPI & $1,00 \pm 0,55^{\mathrm{a}}$ & $1,26 \pm 0,45^{\mathrm{a}}$ & $1,01 \pm 0,34^{\mathrm{a}}$ \\
\hline sSBI & $1,03 \pm 0,13^{\mathrm{a}}$ & $1,23 \pm 0,38^{\mathrm{a}}$ & $1,33 \pm 0,42^{\mathrm{a}}$ \\
\hline sPPD & $2,16 \pm 0,67^{\mathrm{a}}$ & $2,21 \pm 0,50^{\mathrm{a}}$ & $4,26 \pm 1,62^{\mathrm{b}}$ \\
\hline PISF Volume ( $\boldsymbol{\mu l})$ & $0,15 \pm 0,17^{\mathrm{a}}$ & $0,44 \pm 0,25^{\mathrm{b}}$ & $0,62 \pm 0,35^{\mathrm{b}}$ \\
\hline TAOC & $0,46 \pm 0,26^{\mathrm{a}}$ & $0,39 \pm 0,42^{\mathrm{a}}$ & $0,46 \pm 0,27^{\mathrm{a}}$ \\
\hline TOS & $1,38 \pm 0,79^{\mathrm{a}}$ & $1,71 \pm 2,44^{\mathrm{ab}}$ & $3,26 \pm 2,03^{\mathrm{b}}$ \\
\hline OSI & $4,38 \pm 4,06^{\mathrm{a}}$ & $10,81 \pm 12,87^{\mathrm{a}}$ & $14,29 \pm 22,79^{\mathrm{a}}$ \\
\hline MBL & $-{ }^{\mathrm{a}}$ & $-{ }^{\mathrm{a}}$ & $4,35 \pm 1,33^{\mathrm{b}}$ \\
\hline
\end{tabular}

H: Peri-implant health group, PM: Peri-implant mucositis group, PI: Periimplantitis group tPI: Plaque index of mouth, $t \boldsymbol{G l}$ : Gingival index of mouth, tPPD: Periodontal pocket depth of mouth, sPI: Plaque index of sampled implant, sGl: Gingival index of sampled implant, sPPD: Probing pocket depth of sampled implant, MBL: Marjinal Bone Loss of sampled implant, TOS: total oxidant status, TAOC: total antioxidant capacity, OSI: oxidative stress index, TAOC Unit: mmol Trolox Equiv./L, TOS Unit: $\mu \mathrm{mol} H 2 \mathrm{O} 2$ Equiv./L. Descriptive statistic were given as mean \pm std. deviation. Different superscript letter in same column showed Statistically significance $(p<0,05)$.

tPI, tGI, tPPD parameters showed no statistically significant difference between groups. sPI parameter was statistically significantly higher in the peri-implantitis group than the peri-implant healthy group $(p=0,011)$. The $s S B I$ was statistically significantly higher in the peri-implanter mucositis and peri-implantitis groups than the peri-implant healthy group $(p<0,0001)$. The sPPD parameter showed a statistically significant increase in the peri-implantitis group compared to the peri-implant healthy and peri-implanter mucositis group $(p<0,0001)$.

Although the PISF volume was found to be statistically significantly higher in the PM and PI groups compared to the $H$ group ( $p=0,012 ; p<0,0001$; respectively), there was no statistically significant difference between $\mathrm{PM}$ and $\mathrm{PI}$ groups $(p=0,766)$ in terms of PISF volume. The TOS parameter was statistically significantly higher in the $\mathrm{PI}$ group than the $\mathrm{H}$ group $(\mathrm{p}=0.041)$. There was no statistically significant difference between the groups in terms of TAOC and OSI ( $p=0,368, p=0,210$, respectively). MBL parameter was significantly higher in the PI group than in PM and $\mathrm{H}$ groups $(p<0,0001)$.

\section{Discussion}

The increase in the application of dental implants from the past to the present brings many problems. Peri-implant diseases, one of these problems, are turning into a growing problem (3). Thus, the present study was to consist of the $\mathrm{H}, \mathrm{PM}$, and PI groups defined as the recent classification. Also, according to the present study, It can be said that TOS in PISF can increase in patient with peri-implantitis similarly to periodontitis.

Plaque index, GI, and PPD were calculated and recorded to evaluate the patients' periodontal status. These indexes were preferred because they are widely used, and they allow comparison with other studies (6). Acıpınar et al. 
showed that PPD, CAL, $\mathrm{mPI}, \mathrm{GI}$, and $\mathrm{mSBI}$ numbers were significantly higher in PI group than in $\mathrm{H}$ and PM group. Similarly, these clinical parameters were significantly higher in PM group than in $\mathrm{H}$ group (15). Another study conducted by Uzunkaya et al. In individuals with gingivitis, periodontitis, PM, and PI, they showed no significant difference between PM and PI groups in terms of plaque index and GI values, but a significant difference in PPD values (17). Although Gündoğar et al. observed that the PPD, plaque index, and GI parameters were significantly higher in the PM and $\mathrm{PI}$ groups than the $\mathrm{H}$ group and showed no statistically significant difference between PM and PI groups (18). In another study conducted by Akman et al., there were no statistically significant differences among the Healthy/Inflamed Tooth/Implant groups in terms of plaque index, GI, PPD, and CAL values (19). In the present study, SPPD values were statistically significantly higher in the peri-implantitis group than the peri-implant healthy and peri-implant mucositis groups. There was no significant difference between groups in sPI and sGI values. While some of the data of our study are compatible with other studies, some of them not. The difference between these studies is thought to be due to the different inflammatory degrees in the periodontium. Although microbial dental plaque is accepted as the primary etiological factor in peri-implant disease, the host defense system's response to the dental plaque affects the disease's severity and pattern. Changing the immune response given to the etiological factor from person to person makes the course and treatment difficult. Assessing the immune response of host defense system elements to inflammation can help the physician control the current disease. Peri-implant diseases are site-specific; this feature of periimplant diseases has frequently found itself in the literature (20). Since the peri-implant sulcus fluid (PISF) allows local evaluation of the region, the current study was planned precisely for the peri-implant disease and healthy sites. Peri-implant sulcus fluid (PISF) has similar properties to gingival crevicular fluid (GCF) and is among the diagnostic criteria used in the diagnosis and activity of the disease around the implant $(21,22)$. Thus, the PISF sampling method was preferred in the current study because it allows the immediate state of the peri-implant disease's host response to be measured with a non-invasive procedure. One study related to peri-implant tissue's oxidative status conducted by Jazi et al., showed no significant difference between the groups in terms of the TAOC parameter (23). On the other hand, Liskmann et al. showed that the TAOC parameter was significantly lower in peri-implantitis and peri-implant mucositis groups compared to healthy group (24). With respect to recent study, no statistically significant difference was found among the groups in the TAOC parameter. This result is compatible with the results of Jazi et al. 's studies, but it is inconsistent with Liskmann et al.'s results. This difference was thought to be due to the use of PISF in the present study and Jazi et al., but the use of saliva in the Liskmann et al.'s research.
Studies on TAOC, TOS and OSI parameters in peri-implanter diseases are not sufficient in the literature. Therefore, our study was compared with studies examining TAOC, TOS and OSI parameters in periodontal diseases. Toczewska et al. examined TAOC, TOS and OSI parameters in gingival crevicular fluid and saliva in patients with periodontitis. TOS and OSI were significantly higher in periodontitis group than in healthy group in the stimulated, unstimulated saliva and gingival crevicular fluid, while TAOC was lower periodontitis group than in healthy group (25). Baltacıoglu et al. investigated serum and salivary TAOC, TOS and OSI values in chronic and aggressive periodontitis patients. They found that TOS and OSI values were significantly higher and TAOC values was lower in the periodontitis group than to healthy group (26). Zhang et al. found that saliva TAOC values were significantly lower in periodontitis patients compared to the healthy group, but they did not find a significant difference in TOS values (27). Wei et al. found that the TOS parameter before periodontal treatment was significantly higher in gingival crevicular fluid, saliva and serum in chronic periodontitis patients compared to the healthy group. After periodontal treatment, there was no significant difference between the groups in TOS parameters(28). In the study by Jazi et al. could not find any difference between inflamed peri-implant tissue and healthy peri-implant tissue between malondialdehyde and superoxide dismutase levels in PISF, which were observed as parameters of oxidative stress (23). In our study, the TOS parameter was found to be statistically significantly higher in peri-implantitis group compared to peri-implant healthy group. When we examined the TAOC and OSI parameters, no statistically significant difference was found between the groups. These results show that our study and studies conducted on individuals with periodontal disease are generally compatible in terms of TOS parameter but not in terms of TAOC parameter. This incompatibility; Although gingival crevicular fluid and PISF are similar in content, we think that it is due to the different level of response of the antioxidant defense system in case of inflammation.

\section{Conclusion}

To our knowledge, this is the first study to examine oxidative stress markers in peri-implant disease and health. Further studies evaluating periodontal and peri-implant health and disease states will be more useful to shed light on the subject. Within the study's limitations, it can be said that the TOS level in PISF increased in peri-implantitis.

\section{Acknowledgements}

This study was supported by self-funding. The study is a part of Research Assistant Emre Birbiri's specialization thesis in periodontology.

Ethical Approval: The study was approved by Gaziantep University Local Ethics Committee (approval date:23.10.2019, decision number:399) 


\section{Author Contributions:}

Concept: H.G., M.U., E.B.

Literature Review: M.U., E.B.

Design : H.G., E.B.

Data acquisition: M.U., E.B.

Analysis and interpretation: H.G., E.B.

Writing manuscript: M.U., E.B.

Critical revision of manuscript: H.G., M.U.

Conflict of Interest: The authors have no conflicts of interest to declare.

Financial Disclosure: Authors declared no financial support.

\section{References}

1. Belser UC, Mericske-Stern R, Bernard JP, Taylor TD. Prosthetic management of the partially dentate patient with fixed implant restorations. Clin Oral Implants Res. 2000;11(S1):126-45.

2. Schwarz F, Derks J, Monje A, Wang H-L. Peri-implantitis. J Periodontol. 2018;89:267-90.

3. Caton JG, Armitage G, Berglundh T, Chapple ILC, Jepsen S, Kornman KS, et al. A new classification scheme for periodontal and peri-implant diseases and conditions - Introduction and key changes from the 1999 classification . Journal of periodontology. 2018;45:1-8.

4. Araujo MG, Lindhe J. Peri-implant health. J Periodontol. 2018;89:249-56.

5. Heitz-Mayfield LJA, Salvi GE. Peri-implant mucositis. J Periodontol. 2018;89:257-66.

6. Renvert S, Persson GR, Pirih FQ, Camargo PM. Peri-implant health, peri-implant mucositis, and peri-implantitis: Case definitions and diagnostic considerations. J Periodontol. 2018;89:304-12.

7. Candel-Martí M-E, Flichy-Fernández A-J, Alegre-Domingo T, Ata-Ali J, Peñarrocha-Diago MA. Interleukins IL-6, IL-8, IL-10, IL-12 and periimplant disease. An update. Med Oral Patol Oral Cir Bucal. 2011;16:518-21.

8. Phaniendra A, Jestadi DB, Periyasamy L. Free Radicals: Properties, Sources, Targets, and Their Implication in Various Diseases.Indian Journal of Clinical Biochemistry. 2015;30:11-26.

9. Vascotto CTC, Vascotto C, Tiribelli C. Oxidative Stress, Antioxidant Defenses, and the Liver.Studies on Hepatic Disorders, 2015;41-64.

10. Chapple ILC, Matthews JB. The role of reactive oxygen and antioxidant species in periodontal tissue destruction. Periodontology 2000. 2007;43:160-232.

11. Żukowski P, Maciejczyk M, Waszkiel D. Sources of free radicals and oxidative stress in the oral cavity. Arch Oral Biol. 2018;92:8-17.

12. Papapanou PN, Sanz M, Buduneli N, Dietrich $T$, Feres $M$, Fine $\mathrm{DH}$, et al. Periodontitis: Consensus report of workgroup 2 of the 2017 World Workshop on the Classification of Periodontal and Peri-Implant Diseases and Conditions. J Periodontol. 2018;89:173-82.

13. Loe H, Silness J, Löe H, Silness J, Loe H, Silness J. Periodontal Disease in Pregnancy I. Prevalence and Severity. Acta Odontol Scand . 1963;21:533-51.

14. Silness J, Loe H. Periodontal Disease in Pregnancy 11. Correlation Between Oral Hygiene and Periodontal Condition. Acta odontal scand. 1963;22:121-35.
15. Acipinar S, Karsiyaka Hendek M, Olgun E, Kisa U. Evaluation of FGF-23 and 25(OH)D3 levels in peri-implant sulcus fluid in peri-implant health and diseases. Clin Implant Dent Relat Res. 2019;21:1106-12.

16. Erel O. A novel automated direct measurement method for total antioxidant capacity using a new generation, more stable ABTS radical cation. Clin Biochem. 2004;37:277-85.

17. Uzunkaya M, Gundogar H. Evaluation of periostin levels in gingival crevicular fluid and peri-implant sulcus fluid in patients with periodontal and peri-implanter disease: A cross-sectional study. Ann Med Res . 2019;26(10):2093-97.

18. Gundogar H, Ozsoy B, Uzunkaya M, Senyurt SZ EK. Effect of peri-implant disease on adropin levels: A cross-sectional pilot study. Eur J Ther. 2020;26:61-5.

19. Akman AC, Askin SB, Guncu GN, Nohutcu RM. Evaluation of Gingival Crevicular Fluid and Peri-Implant Sulcus Fluid Levels of Periostin: A Preliminary Report. J Periodontol. 2018;89(2):195-202.

20. Salvi GE, Cosgarea R, Sculean A. Prevalence and Mechanisms of Peri-implant Diseases. J Dent Res. 2017;96:31-7.

21. Javed F, Al-Hezaimi K, Salameh Z, Almas K, Romanos GE. Proinflammatory cytokines in the crevicular fluid of patients with peri-implantitis.Cytokine. 2011;53:8-12.

22. Kaklamanos EG, Tsalikis L. A review on peri-implant crevicular fluid assays potential in monitoring and predicting peri-implant tissue responses. Journal of the International Academy of Periodontology. 2002;4:49-59.

23. Mousavi Jazi M, Sadeghi Pour Rodsari HR, Mirmiran F. Level of Oxidative Stress Markers in Peri-Implant Crevicular Fluid and Their Correlation with Clinical Parameters. J Dent (Tehran). 2015;12:340-6.

24. Liskmann S, Vihalemm T, Salum O, Zilmer K, Fischer K, Zilmer M. Characterization of the antioxidant profile of human saliva in peri-implant health and disease. Clin Oral Implants Res. 2007;18:27-33.

25. Toczewska J, Maciejczyk M, Konopka T, Zalewska A. Total oxidant and antioxidant capacity of gingival crevicular fluid and saliva in patients with periodontitis: Review and clinical study. Antioxidants. 2020;9(5):450

26. Baltacıoğlu E, Yuva P, Aydın G, Alver A, Kahraman C, Karabulut $E$, et al. Lipid Peroxidation Levels and Total Oxidant/Antioxidant Status in Serum and Saliva From Patients With Chronic and Aggressive Periodontitis. Oxidative Stress Index: A New Biomarker for Periodontal Disease? J Periodontol. 2014;85:1432-41.

27. Zhang $\mathrm{T}$, Andrukhov $\mathrm{O}$, Haririan $\mathrm{H}$, Müller-Kern M, Liu S, Liu $Z$, et al. Total antioxidant capacity and total oxidant status in saliva of periodontitis patients in relation to bacterial load. Front Cell Infect Microbiol. 2016;5:97

28. Wei D, Zhang XL, Wang YZ, Yang CX, Chen G. Lipid peroxidation levels, total oxidant status and superoxide dismutase in serum, saliva and gingival crevicular fluid in chronic periodontitis patients before and after periodontal therapy. Aust Dent J. 2010;55(1):70-8. 